\title{
Effect of Weight Gain Prevention during Menopause
}

\author{
Dame Evalina Simangunsong ${ }^{1}$, Rosa Delima Ekwantini ${ }^{2}$, and Marlisa ${ }^{3}$ \\ \{dameevalinas8@gmail.com ${ }^{1}$, rosadlm.delima@gmail.com², marlisanurse@gmail.com ${ }^{3}$ \} \\ Jurusan Keperawatan Poltekkes Kemenkes Medan ${ }^{13}$ \\ Jurusan Keperawatan Poltekkes Kemenkes DI Yogyakarta²
}

\begin{abstract}
Estrogen hormone imbalances can have a variety of impacts when entering menopause and after menopause. Weight gain will happen easily and may be inevitable. This condition is associated with a high risk of cardiovascular and metabolic diseases associated with its quality of life and sexual function. This study aims to apply the prevention of weight gain through the provision of health information about menopause and physical exercise as well as the regulation of the frequency of eating with a balanced diet. The initial stage of the study was conducted to look at the lifestyle of women in the face of menopause and continued by providing interventions "Obesity Prevention Movement " (GERNOBES), conducted in Medan against 35 menopausal women. The results showed, $91.4 \%$ were overweight and their blood pressure was above normal as much as $74.3 \%$. Behavior prevention efforts to increase weight are still low. T-dependent test results showed there was a difference in the average score of knowledge, attitude and action on the measurement of pretest and posttest in the intervention group significantly, the $p$ value $<0.05$, while in the control group it was not $(p>0.05)$ Interventions can change the behavior and pattern of physical activity and frequency of eating. Wilcoxon test results showed an increase in the frequency of eating and physical activity in the intervention group with a p-value of $<0.001$ It is recommended to socialize health information related to menopause on an ongoing basis.
\end{abstract}

Keywords: Menopause; Physical activity; Obesity

\section{Introduction}

Weight gain will occur easily and maybe unavoidable when entering menopause and after menopause. After menopause, estrogen levels will begin to decrease and metabolism slows down. Hormonal changes during perimenopausal times substantially contribute to an increase in abdominal obesity that causes physical and psychological morbidity. The prevalence of central obesity in Indonesia is increasing. In 2013 the central obesity rate only reached 26.6 percent, then in 2018, it increased to 31 percent. A third of Indonesian women over the age of 18 are overweight or obese. Sixteen regions in Indonesia have higher obesity rates than the national figure of 27\%. The area includes West Java, Bali, Papua, DI. Yogyakarta, Aceh, Central Sulawesi, East Java, Bangka Belitung, North Sumatra, West Papua, Riau Islands, North Maluku, East Kalimantan, DKI Jakarta, Gorontalo, and North Sulawesi (1).

Menopausal women contributed to the increase. The results of a study conducted by Simangunsong \& Wahyuni (2018), in Pematangsiantar city found as many as $98.9 \%(\mathrm{n}=70)$ menopausal women with obese weight and obesity (2). Rosdiana et al (2017), that there is a relationship between Body Mass Index (BMI) and hypertension incidence. PERKI 2015, reported as many as $29 \%$ (out of 2762 patients who entered IGD Heart Hospital and Harapan 
Kita) with diagnosis of Acute Coronary Syndrome (SKA) is a woman with an average of 60 years. (National Center for Health Statistics, 2016), systolic blood pressure increases sharply in postmenopausal compared to premenopausal, this is associated with decreased estrogen hormone and weight gain (3).

Weight gain with age needs to be watched, adiposity or obesity, and impaired carbohydrate metabolism. This can occur as a result of changes in hormone balance that affect weight control. (4) Menopausal women are susceptible to the incidence of deadly degenerative diseases that stem from the risk of obesity that menopausal women will experience. Prevention efforts with health education in avoiding risky behaviors in menopausal women need to be emphasized. with premenopausal empowerment model (PEM) training successfully raised awareness for premenopausal women in Pematangsiantar City(5).

Prevent by creating a movement "GERNOBES", by designing media that is attached to women. Shopping bags, glass mugs, and pocketbooks titled "Adaptation of New Habits for Menopausal Women to Avoid Obesity in The Covid-19 Pandemic Period" which disabled and printed containing health information about the setting of frequency and diet and regular activities in the form of regular exercise is expected to be able to remind and realize and inform the health message for herself in particular and the surrounding community in general.

\section{Research and Methodology}

\subsection{Research Issues}

The formulation of this research problem is " How does the prevention effect of weight gain on menopausal women? “

\subsection{The Purpose of Research}

This study aims to analyze the differences in the effect of weight gain prevention in menopausal women on the behavior, patterns, and frequency of balanced eating as well as physical activity of menopausal women through the provision of health information about menopause and physical exercise as well as the regulation of eating frequency with a balanced diet.

\subsection{Types of Research}

This type of research is a research survey with explanatory type and quasi-experimental with design two group design pretest-posttest with the control group. The study was reviewed by identifying menopausal female characteristics, menopausal complaints, behavior, physical activity, and frequency of eating against weight gain control efforts. Three times over three months, the intervention group was given health education on weight gain prevention efforts through an action named by researchers with "GERNOBES" or Obesity Prevention Movement.

This intervention is designed by empowering menopausal who are researched by providing health education interventions about menopause, balanced eating arrangements, regular eating frequency, and physical activity that must be done. This intervention is done by providing media close to menopausal women such as shopping bags, mugs, booklets, and leaflets. Shopping bags and mugs containing pictorial messages about "GERNOBES". 


\subsection{Location of Research}

Research conducted in Medan, with the consideration of elections based on sub-districts with the highest number of female populations in the age group of 45- 55 years.

\subsection{The Time of the study}

This research has begun with preliminary data collection in November 2019. The research was conducted from August to September 2020 during the Adaptation of New Habits during the Covid-19 pandemic.

\subsection{Population and sample}

The sample size is calculated using a sampling formula at a confidence level of $95 \%$ (Z1$\alpha / 2=1.96)$ with a test strength of $90 \%(Z 1-\beta=1,282)$, assuming the proportion of unexposed groups (P2) $50 \%$ and the estimated relative risk (RR) of 1.75 (Lemeshow et al. 1997) as follows (6):

$$
\begin{gathered}
n=\frac{\left\{Z_{1-\alpha / 2} \sqrt{2 P(1-P)}+Z_{1-\beta} \sqrt{(P 1(1-P 1)+P 2(1-P 2)}\right\}^{2}}{(P 1-P 2)^{2}} \\
\mathrm{P}_{1}=(\mathrm{RR}) \mathrm{P}_{2}=(1,75) 0,5 .=0,88 \\
\mathrm{P}=\left(\mathrm{P}_{1}+\mathrm{P}_{2}\right) / 2 \quad=(0,88+0,5) / 2=0,69
\end{gathered}
$$

$\mathrm{n}=29,98 \sim 30$

The total number of samples obtained by 30 people and to avoid samples that drop out or lose to follow up, then the maximum sample size took 35 people for the intervention group and 35 for the control group (1:1). The selection of samples in the study was conducted with purposive random sampling techniques based on the following criteria:

Inclusion Criteria:

a. Women aged $50-55$ years.

b. It has been 3 years of menopause.

c. Has no history of uterus removal.

d. Not undergoing hormonal treatment and diet programs.

\subsection{Data Collection Method}

The type of data source is about where the data is obtained. The data in this study is sourced from primary data, such as the characteristics of menopausal women, the results of physical examination, behaviors (knowledge, attitudes, and actions), physical activity, and frequency of eating. Data measurement is performed before and after giving intervention. Interventions are made in the form of socialization of information about menopause (starting from understanding, changes experienced, efforts to overcome complaints experienced (while maintaining weight balance) through demonstrations of balanced eating arrangements and exercise / physical activity. Interventions were made three times.

\subsection{Data processing}

The data that has been collected will then be processed how to encrypt data into computer software namely SPSS (Statistical Product and Service Solutions). 


\section{Research and Measurement Instruments}

The data collection tools and measurements in this study can be described as follows:

a. A checklist sheet containing the respondent's bio (age, occupation, menopausal age, menopause, and physical examination).

b. Instruments of menopausal women's behavior (aspects of knowledge, attitudes, and actions)

c. Weight gains control assessment instrument with an assessment of the duration and frequency of physical activity and frequency of eating menopausal women.

The data collected is analyzed to describe all variables studied. The collected data is analyzed with Univariate and Bivariate Analysis. Statistical tests used, when distributed normally, data tested with unconscionable T-test (T dependent Test) and if not distributed normal data in tests with Wilcoxon Test at 95\% trust level $(\alpha=0.05), \mathrm{p}<0.05$ then the above variable is expressed to differ significantly.

\section{Result and Discussion}

As for the results of the research conducted, can be seen in the table below:

Table 1. Overview of body mass index and blood pressure

\begin{tabular}{lllll}
\hline \multicolumn{1}{c}{$\begin{array}{c}\text { Body Mass index and blood } \\
\text { pressure }\end{array}$} & \multicolumn{3}{c}{ Intervention } & Control \\
\cline { 2 - 5 } & $\mathrm{n}(35)$ & $\%$ & $\mathrm{n}(35)$ & $\%$ \\
\hline Body Mass index & 1 & 2.9 & 5 & 14,3 \\
Normal & 9 & 25,7 & 13 & 37,1 \\
Fat & 25 & 71,4 & 17 & 48,6 \\
Obesity & 35 & 100 & 35 & 100 \\
\hline Total & & & & \\
\hline Blood pressure & 8 & 22,9 & 12 & 34.3 \\
Normal & 6 & 17.1 & 8 & 22,9 \\
Prehypertension & 11 & 31,4 & 6 & 17,1 \\
Hypertension (1) & 10 & 28,6 & 9 & 25.7 \\
Hypertension (2) & 35 & 100 & 35 & 100 \\
\hline Total & & & & \\
\hline
\end{tabular}

The table above shows the results of measuring the body mass index of menopausal women in the intervention group, found as much as $97.1 \%$ with the category of fat and obese and in the control group as much as $85.7 \%$. Blood pressure measurement results in the intervention group, found only $22.9 \%$ were at the normal limit and in the control group, $34.3 \%$.

Table 2. Average Distribution of Menopause Age in Intervention Group and Control Group of Menopausal Women in Medan by 2020

\begin{tabular}{ll}
\hline Age of menopause & Mean \pm SD \\
\hline Intervention group. & $48,89 \pm 1,94$ \\
Control group. & $48,86 \pm 1,52$ \\
\hline
\end{tabular}

The table above shows the average age of menopause in the intervention group was 48.89 \pm 1.94 and in the control group $48.86 \pm 1.52$. 
Table 3. Description of the behavior of menopausal women

\begin{tabular}{lllll}
\hline \multirow{2}{*}{ Behavior } & \multicolumn{3}{c}{ Intervention group } & \multicolumn{2}{c}{ Control group } \\
\cline { 2 - 5 } & $\mathrm{n}$ & $\%$ & $\mathrm{n}$ & $\%$ \\
\hline Knowledge & 27 & 77,1 & 27 & 77,1 \\
Low & 8 & 22.9 & 8 & 22,9 \\
High & & & & \\
\hline Attitude & 33 & 94,3 & 28 & 80 \\
Disagree & 2 & 5.7 & 7 & 20 \\
Agree & & & & \\
\hline Action & 27 & 77,1 & 26 & 74,3 \\
Not Do & 8 & 22.9 & 9 & 25,7 \\
Do & & & & \\
\hline
\end{tabular}

The table above shows the results of measurements of the behavior of menopausal women (knowledge, attitudes, and actions) that are still low against efforts to prevent weight gain during menopause.

Table 4. Frequency of eating and physical activity of menopausal women

\begin{tabular}{lcccc}
\hline & \multicolumn{2}{c}{ Intervention group } & \multicolumn{2}{c}{ Control group } \\
\cline { 2 - 5 } & $\mathbf{n}$ & $\mathbf{\%}$ & $\mathbf{n}$ & $\mathbf{\%}$ \\
\hline Frequency of eating & 0 & 0 & 0 & 0 \\
Regular, Irregular & 35 & 100 & 35 & 100 \\
\hline Physical activity & & & & \\
$<3$ times a week & 0 & 0 & 0 & 0 \\
$\geq 3$ times a week & 35 & 100 & 35 & 100 \\
\hline
\end{tabular}

The table above shows the diet frequency of menopausal mothers at two research sites in the control group classified on the frequency of irregular eating and physical activity or exercise that mother did every day before being given the majority intervention in classed on less physical activity.

Table 5. Differences in average behavior scores of menopausal women before and after intervention

\begin{tabular}{ccccccc}
\hline \multicolumn{7}{c}{ Average } \\
Variables/Groups & Pretest & Posttest & Difference & SD & $p^{*}$ & $\begin{array}{c}\text { t-dependent } \\
\text { test }\end{array}$ \\
\hline Knowledge & & & & & & \\
Intervention & 11,60 & 14,20 & 2.600 & 2.626 & $<0,001$ & 5.858 \\
Control & 12.91 & 13.69 & .771 & 2.808 & 0.113 & 1.625 \\
\hline Attitude & & & & & & \\
Intervention & 9.83 & 11.17 & 1.343 & 2.578 & 0,004 & 3.082 \\
Control & 10,57 & 10.51 & .057 & 1.083 & 0,75 & 0.312 \\
\hline Action & & & & & & \\
Intervention & 10.80 & 11.40 & 0,600 & 1.143 & 0,004 & 3.106 \\
Control & 10.34 & 10.06 & .286 & .957 & 0.086 & 0.086 \\
\hline P*t
\end{tabular}

$\mathrm{P}^{*}$ : t-dependent test 
In the table above, shows there is a difference in the average score of knowledge, attitude and actions on the measurement of pretest and posttest in the intervention group significantly.

Table 6. Distribution of Eating Frequency and Physical Activity Before and After Intervention

\begin{tabular}{lcccc}
\hline \multicolumn{1}{c}{ Variable } & Average & Minimum & Maximum & P \\
\hline Frequency of eating & & & & \\
Pretest & 2.20 & 1 & 2 & $<0,001$ \\
Posttest & 4.06 & 3 & 5 & $<0,001$ \\
\hline Physical activity & & & & \\
Pretest & 0,71 & 0 & 2 & $<0,001$ \\
Posttest & 2,91 & 1 & 5 & $<0,001$ \\
\hline P*: Wilcoxon Test & & & &
\end{tabular}

Wilcoxon test results showed an increase in the frequency of eating and physical activity in the intervention group with a p-value of $<0.001$, it can be concluded that there are significant differences in diet and physical activity before and after the intervention.

\section{Discussion}

Identification of menopausal women's behavior towards the prevention of weight gain during menopause, consisting of aspects of knowledge, attitudes, and actions shows that in both research sites, the majority still have less knowledge, disagree attitudes, and have not taken action against the desired efforts at the initial assessment of the research process. First intervention can change the behavior of menopausal women to their knowledge of weight gain prevention efforts, accompanied by an agreed response to make changes and willingness to make recommended efforts to be made to maintain weight balance.

Intervention groups are given a variety of media that are considered to help them make changes independently to maintain health and improve the quality of life of menopausal women. A pocketbook containing information about menopause and complaints experienced, alternative actions are taken to reduce complaints, and descriptions of muscle and bone strength exercises as well as balanced nutritional information in the age group, are available in the pocketbook. Also given bags and mugs containing images of health messages for menopausal women as an effort to make a movement, which in this study is referred to as "GERNOBES (Obesity Prevention Movement)" which is expected to be a chain media that can be read by anyone when used.

Education in the field of health is a provision of information to individuals, families, or groups continuously and continuously and the process of helping, so that there is a change from ignorance to knowing or conscious (an aspect of knowledge), from known to want (an aspect of attitude) and from willing to be able to carry out the introduced behavior (an aspect of action). Community empowerment is a variety of elements that allow the community to survive that can develop themselves and achieve progress. Socialization about health directs people to be aware of their abilities and utilize existing strengths to be empowered and can be used for meaningful activities even to meet the needs of life independently.

Ministry of Health, 2013 realized that community empowerment in the field of health, referring to the long-term goals of the health sector, namely: 1) improving the ability of the community to help itself in the field of health, 2) improving the quality of the environment that 
can guarantee health, 3) improving the nutritional status of the community, 4) reduction of pain (morbidity) and death (mortality), 5) development of quality families (7). Health education on healthy lifestyles needs to be emphasized in prevention efforts against the disease. A healthy lifestyle is a lifestyle by paying attention to certain factors that affect health such as food and exercise. Healthy living is living with a healthy physical, psychological, environmental, and financial, adequate and good. The lifestyle of the individual, which is characterized by the pattern of behavior of the individual will have an impact on the health of the individual and subsequently on others. People who regularly practice life habits tend to be healthier and live longer.

\section{Frequency of Eating and Physical Activity}

The results of the identification obtained to the frequency of eating and physical activity performed by menopausal women in their daily life in the identification of preliminary data showed, that the menopausal women studied did not yet know the importance of dietary regulation and frequency of regular eating and regular physical activity that should be done in menopause. Both of those things become very important to prevent the occurrence of weight gain during menopause. Various factors that become the basis of health education about diet in menopausal women are due to changes in the metabolism of carbohydrates, fats, and proteins that will be experienced due to hormonal fluctuations and the tendency of adult age group activity patterns that affect unbalanced food consumption behavior. Increased risk of exposure to pollution and unsafe foods, availability of a variety of ready-to-eat and ready meals, and ignorance about nutrition for women working outside the home. The working-age group tends to be light or relaxed (sedentary life). Therefore, attention to balanced nutritional behavior needs to be improved to achieve a healthy, active, and productive lifestyle.

The regulation of regular eating patterns and frequencies needs to be socialized in menopausal women, given the changes in hormone production experienced. The deficiency of estrogen hormone in the body will result in changes in the metabolism of carbohydrates, proteins, and fats. Hormonal changes during the perimenopause period substantially contribute to an increase in abdominal obesity that causes physical and psychological morbidity. Being overweight in middle age in addition to being associated with an increased risk of cardiovascular and metabolic diseases, also affects the quality of life and sexual function (8).

The results of a study conducted by researchers in 2017 on the frequency and diet of a regular and balanced. Data found that as many as $76 \%(n=70)$ women often neglect breakfast for various reasons, including not having time and fear of fat. There are still many women who are found to have the wrong perception in maintaining weight balance. Women do not understand that weight gain occurs due to impaired metabolism as a result of the irregularity of eating every day (9).

To improve changes in the metabolism of carbohydrates, proteins, and fats due to fluctuations in hormones in women, then things to note are: Principles of creating thermogenic effects of food (TEF) with i) Eat at least six times per day: breakfast, snacks, lunch, afternoon snacks, dinner, evening snacks, ii) Reduce fat intake, increase carbohydrate intake and eat enough protein. Do not eat more than 30 grams of fat per day, iii) eat more than 1000 calories per day (4). Energy adequacy in adult women aged 30-49 years recommended for Indonesians per day is 2150 kilo calories. Energy is one of the results of the metabolism of carbohydrates, proteins, and fats. Energy serves as an energy substance for metabolism.

Growth, temperature regulation, and physical activity. Excess energy is stored in glycogen form as a short-term energy store and the form of fat as a long-term reserve (10). Physical activity is any body movement produced by skeletal muscle that increases energy expenditure, 
which is categorized as sufficient if a person performs physical exercise or exercise for 30 minutes every day or at least 3-5 days a week. Lack of physical activity, is an independent risk factor for the occurrence of chronic diseases, and overall is estimated to cause death globally (11).

Physical activities in the form of sports that can be done include healthy walking and jogging, playing tennis, playing badminton, football, aerobic gymnastics, breathing gymnastics, swimming, playing basketball, playing volleyball, cycling, weight training, dumbbell and other movement modifications such as mountain climbing. The benefits of physical activity to health are: (a) avoid heart disease, stroke, osteoporosis, cancer, high blood pressure, diabetes, and others; (b) controlled weight, (c) more flexible muscles and stronger bones, (d) ideal and proportional body shape, (e) more confident, (f) more powerful and fit, (g) in general the state of health becomes better due to the oxygenation process or smooth flow of blood in carrying oxygen throughout the body tissues (12). Regular physical activity and becoming one habit will increase physical endurance. Physical exercise when done properly, correctly, regularly, and measurably can improve physical endurance, health, and fitness (11).

The Lancet 2012, suggests less physical activity causes 6-10\% of non-communicable diseases such as coronary heart disease, type 2 diabetes, bowel cancer, so it is expected to do a brisk walk 15-30 minutes every day. The wrong view when considering no longer need to exercise because in every day already actively moving or has done a lot of household chores. It is recommended to perform physical activity for 3-5.5 hours in one day. While the recommended portion to exercise at least 150 minutes in 1 week or 3 times in 1 week for 50 minutes or five times in 1 week for 30 minutes and better if routine every day (13).

Both of those activities are very important to be converted into a patterned activity and become routinely performed by menopausal women to balance their weight. If this effort can be carried out normally, prevention to avoid the incidence of obesity with age will be suppressed, to reduce the risk of non-communicable diseases that are very threatening to the life of menopausal women.

\section{Conclusion}

Behavior towards efforts to prevent weight gain during menopause and a healthy lifestyle during menopause needs to be socialized continuously to support the quality of life of menopausal women. Health promotion efforts that are on target and as early as possible need to be done, women need to be equipped about reproductive health during menopause at an early age, in order to make efforts to intervene against symptoms and complaints that will arise.

\section{References}

[1] Kementerian Kesehatan RI. Laporan Riskesdas 2018. Lap Nas Riskesdas 2018 [Internet]. 2018;53(9):154-65. Available from: http://www.yankes.kemkes.go.id/assets/downloads/PMK No. 57 Tahun 2013 tentang PTRM.pdf

[2] Simangunsong D.E WT. Decreasing Menopause Complaints with Strength Training of Muscle, Bone, and Joint. J Kesehat Manarang [Internet]. 2020;6(1):1-7. Available from: http://jurnal.poltekkesmamuju.ac.id/index.php/m/article/view/175

[3] Rosdiana et al. Implementasi Program Pengelolaan Penyakit Kronis (Prolanis). Higeia J Public Heal Res Dev. 2017; 
[4] Dr. Mickey Harpaz PhD (Author) RW. Menopause Reset! Reverse Weight Gain, Speed Fat Loss, and Get Your Body Back in 3 Simple Steps Kindle Edition [Internet]. Rodale Books; Available from: https://www.amazon.com/Menopause-Reset-Reverse-Weight-Simpleebook/dp/B004I43HJ0

[5] D.E. S, M.F.G. S, R.S. T, R. L. The impact of premenopausal empowerment model-based health belief model to changes in physical activity levels in controlling complaints of perimenopausal women in Pematangsiantar City, Indonesia, 2017. G Ital di Ostet e Ginecol. 2017;

[6] Lemeshow, S., Hosmer, D.W., Klar, J., Lwanga SK. Lemeshow, S., Hosmer, Besar Sampel dalam Penelitian Kesehatan. Jogjakarta: Gajahmada University Press; 1997.

[7] Kemenkes RI. Pusat Data dan Informasi Profil Kesehatan Indonesia Tahun 2016. InfoDATIN. 2017;

[8] Davis SR, Castelo-Branco C, Chedraui P, Lumsden MA, Nappi RE, Shah D, et al. Understanding weight gain at menopause. Climacteric. 2012.

[9] Simangunsong, D. E. Rika Subarniati Triyoga, Muhammad Fidel Ganis Siregar RL. The Effect of the Intervention "Pramenopause Empowerment Model (PEM)" Based on Health Belief Against the Balanced Dietary Changes in the Control of Perimenopause Complaints in Pematangsiantar 2017. Int J Sci Res. 2017;

[10] Kemenkes RI. Hipertensi. Infodatin Pus dan Inf Kementeri Kesehat RI. 2014;

[11] Organization WH. Global Recommendations on Physical Activity for Health. In 2010. Available from: https://www.who.int/dietphysicalactivity/global-PA-recs-2010.pdf

[12] Agi Ginanjar, Adang Suherman, Tite Juliantine YH. Jurnal Pendidikan Jasmani dan Olahraga. Pendidik Jasm Olahraga [Internet]. 2018;3(1):122-8. Available from: http://ejournal.upi.edu/index.php/penjas/index

[13] Guthold R, Stevens GA, Riley LM, Bull FC. Worldwide trends in insufficient physical activity from 2001 to 2016: a pooled analysis of 358 population-based surveys with 1.9 million participants. Lancet Glob Heal [Internet]. 2018;6(10): e1077-86. Available from: http://dx.doi.org/10.1016/S2214-109X(18)30357-7 